\title{
CIRCULATION CHANGES AND TELECONNECTIONS BETWEEN GLACIAL ADVANCES ON THE WEST COAST OF NEW ZEALAND AND EXTENDED SPELLS OF DROUGHT YEARS IN SOUTH AFRICA
}

\author{
P. D. TYSON*1, A. P. STURMAN ${ }^{2}$, B. B. FITZHARRIS ${ }^{3}$, S. J. MASON ${ }^{1}$ AND I. F. OWENS ${ }^{2}$ \\ ${ }^{1}$ Climatology Research Group, University of the Witwatersrand, PO Wits, 2050, South Africa \\ email:pdt@crg.bpb.wits.ac.za, \\ email: simon@crg.bpb.wits.ac.za \\ ${ }^{2}$ Department of Geography, University of Canterbury, PO Box 4800, Christchurch, New Zealand \\ email: a.sturman@geog.canterbury.ac.nz, \\ i.owens@geog.canterbury.ac.nz \\ ${ }^{3}$ Department of Geography, University of Otago, PO Box 56, Dunedin, New Zealand \\ email:GEOG03@rivendell.otago.ac.nz \\ Received 18 November 1996 \\ Revised 16 May 1997 \\ Accepted 20 May 1997
}

\begin{abstract}
Twentieth century changes in the terminal position of the Franz Josef Glacier on the west coast of New Zealand are compared with an area-averaged mean annual rainfall series for the summer rainfall region of South Africa. Distinctive teleconnections are evident in an out-of-phase relationship between the two series, each of which exhibits an oscillation of 18-20 years. Periods of glacial advance are shown to coincide with extended dry spells in South Africa, when drought years are prevalent.

Reconstructed pressure anomaly fields are presented for periods of advance and recession of the glacier and for the interdecadal wet and dry spells in South Africa. In both cases major regional atmospheric circulation adjustments take place in a quasi-regular fashion over time to produce an enhancement in westerly airflow during the periods of drought in Africa and glacial advance on the west coast of New Zealand. Extended wet periods and glacial recession are likewise shown to be associated with an enhancement of easterly components of the circulation. Changes in precipitation, temperature and moisture transport are examined and associations with the Southern Oscillation Index are investigated.

Franz Josef glacial advances are shown to occur 4-5 years after the onset of enhanced south-westerly airflow on to the west coast of New Zealand. Advances occur on average 4 years after the onset of extended dry spells in South Africa. Similar atmospheric circulation anomalies in the respective sectors of the Southern Hemisphere and adjustments in the locations of the positions of the ridges in standing wave three are responsible for this correspondence. (C) 1997 Royal Meteorological Society. Int. J. Climatol., Vol. 17: 1499-1512 (1997)
\end{abstract}

(No. of Figures: 5. No. of Tables: 0. No. of References: 89)

KEY WORDS: climatic change; glacial response; circulation changes; inter-decadal variability; New Zealand; South Africa; teleconnections.

\section{INTRODUCTION}

Glaciers have long been recognized as sensitive indicators of climatic change and variability. A recent review of glacier response to climate is given by Raper et al. (1996). Investigation of 127 glaciers in the New Zealand Southern Alps reveals that since the end of the Little Ice Age in the mid-nineteenth century they have diminished by 25 per cent in areal extent and shortened by 38 per cent (Chinn, 1996). The maximum extent of the steep South Island west coast glaciers was reached in 1750 during the Little Ice Age (Lawrence and Lawrence, 1965). The most rapid retreat from the advance at that time has been from the 1890s onwards (Chinn, 1996). Within the general recession, some glaciers, for example the Franz Josef, have shown regular periods of minor advance.

\footnotetext{
*Correspondence to: P. D. Tyson
} 
The character of moraines in the lower Waiho valley of the west coast of New Zealand at about $43^{\circ} \mathrm{S}$ suggests that the Franz Josef Glacier maintained comparatively stable terminal positions during the late Pleistocene and early Holocene (Brazier et al., 1992). Following the amelioration of climate at the end of the Little Ice Age, the glacier has been in general retreat (Chinn, 1989, 1996). However, it was only after the late-nineteenth century that the glacier lost its relative stability (Hessell, 1983; Chinn, 1989, 1995, 1996) and began its general post-Little Ice Age retreat that has been punctuated with minor yet significant advances at intervals of 16 to 24 years during the twentieth century (Chinn, 1989, 1996). The general glacier attenuation has been attributed to temperature changes associated with global warming (Salinger et al., 1983) and to regional precipitation changes (Suggate, 1950; Soons, 1971; Hessell, 1983; Brazier et al., 1992; Fitzharris et al., 1992) and associated circulation changes (Fitzharris et al., 1992; Woo and Fitzharris, 1992; Hooker, 1995). It is evident that both temperature and precipitation factors contribute to glacier advance and retreat. The effect of global warming on general glacier recession cannot be ignored in the wider context and over longer time-scales, whereas regional precipitation and circulation changes exert decisive control on the advancing of specific glaciers, such as the Franz Josef. Local changes in temperature also control the extent to which precipitation falls as snow and not rain.

In the southern African sector of the Southern Hemisphere, $150^{\circ}(\mathrm{ca} .16000 \mathrm{~km})$ to the west of New Zealand, the occurrence of extended spells of wet and dry years during the twentieth century has been studied extensively (for reviews see Tyson, 1986, 1993). The alternating spells are associated with an approximately 18-year oscillation in rainfall over the summer rainfall region of the subcontinent (Tyson, 1971 Tyson et al., 1975). The oscillation extends north from South Africa into Zimbabwe (Ngara et al., 1983). In South Africa it has been traced back in time through tree ring series to the early-seventeenth century (Visagie, 1885). Keen (1971) and Tyson et al. (1975) demonstrated an inverse oscillation in mean annual temperature, with lower temperatures being a function of increased cloud cover and a diminution in solar radiation. The wet and dry conditions have been linked on inter-annual to decadal scales to circulation changes in general (Miron and Tyson, 1984; Tyson, 1986), to ENSO (Lindesay, 1988; van Heerden et al., 1988; Jury et al., 1994; Jury, 1996), sea surface temperature changes (Walker, 1990; Jury and Pathack, 1991; Mason, 1995) and the Quasi-biennial Oscillation (Mason and Tyson, 1992; Mason and Lindesay, 1993; Jury et al., 1994).

When compared, the twentieth century advances of the Franz Josef Glacier and the southern African rainfall changes show a remarkable association. All the glacial advances occur during extended drought periods in southern Africa (Figure 1). The high value of spatially averaged rainfall in 1988-1989 occurred as a consequence of heavy rains in the central parts of the country only. In many other parts, notably eastern areas, the prolonged drought of the 1980s and early 1990s continued unbroken (Mason, 1996). The most recent dry spell in South Africa was one of the longest on record; the most recent advance of the Franz Josef Glacier has been the longest and strongest this century.

In this paper, the teleconnection between South African rainfall and the advances of the Franz Josef Glacier are examined. The atmospheric circulation changes responsible for variations in regional precipitation are considered and it is shown that systematic hemispheric adjustments in the general circulation are responsible for bringing about the synchronous New Zealand west coast glacial advances and the dry spells of South Africa.

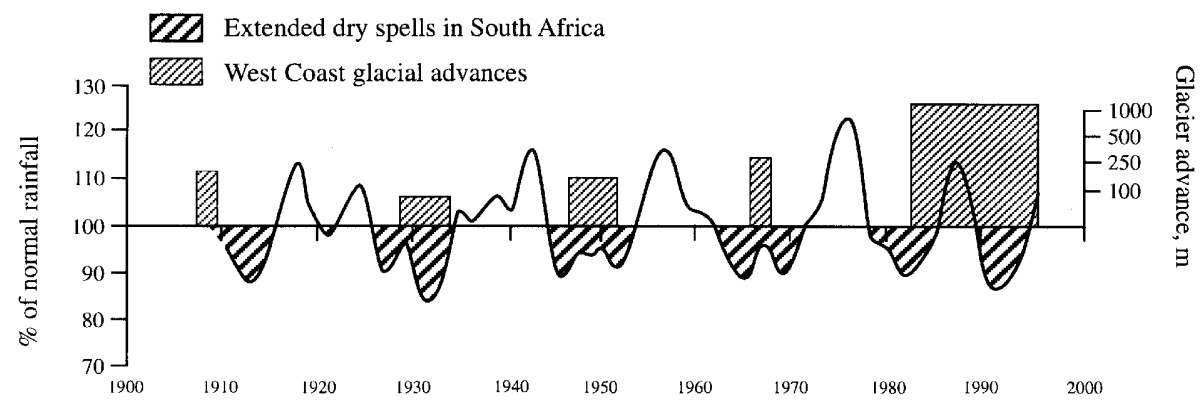

Figure 1. Twentieth century advances of the Franz Josef Glacier (modified after Chinn, 1995, 1997) and area mean summer rainfall region rainfall changes over South Africa (modified after Tyson, 1986). The rainfall series has been smoothed using a nine-term binomial filter. The area-mean rainfall index has been calculated using 430 stations for the period 1930-1931 to 1995-1996 and 59 stations for 1910-1911 to 1929-1930 


\section{THE FRANZ JOSEF GLACIER ADVANCES}

New Zealand has over 3000 glaciers, with an estimated ice volume of $53.3 \mathrm{~km}^{3}$ and a total surface area of 1159 $\mathrm{km}^{2}$ (Chinn, 1989). The Franz Josef Glacier is a large mountain glacier to the west of the South Island main divide. It occurs at approximately $43^{\circ} \mathrm{S}, 170^{\circ} \mathrm{E}$ and has a névé field covering $c a .29 \mathrm{~km}^{2}$ and rising to an elevation of about $3000 \mathrm{~m}$. As of 1996 the glacier was $11.5 \mathrm{~km}$ long and descended steeply as a narrow tongue in a series of icefalls to a terminal position at an altitude of $250 \mathrm{~m}$. Precipitation along the coastal plain to the west of the glacier is of the order of $3 \mathrm{~m}$ per annum. Just to the west of the Southern Alps, which exceed $2500 \mathrm{~m}$ in many places and reach a maximum height of $3754 \mathrm{~m}$ at Mount Cook, annual precipitation exceeds $11 \mathrm{~m}$ (Wratt et al., 1996). The geometry of the glacier and its catchment ensures that it gives a good, clean signal of climate forcing (Woo and Fitzharris, 1992).

Periods of positive mass balance, when catchment accumulation exceeds terminal and surface ablation, produce advances in the glacier; periods of negative balance, when the opposite prevails, are associated with retreat. With the present configuration of the glacier, only small changes in the mass balance are required to trigger an advance (Brazier et al., 1992). Variations in cumulative mass balance correspond to patterns of advance and retreat of the glacier (Woo and Fitzharris, 1992).

Most glaciers in the world have response times to changes in climate that range between 10 and 50 years (Oerlemans, 1994). Models have been proposed by Johannesson et al. (1989) and Haeberli (1995) that depend on volume variations related to thickness changes over the length of the glacier and terminus velocities. Using these models, response times for the Franz Josef Glacier have been calculated to be 7 years (Hooker, 1995) in comparison with observed times of 5-7 years (Suggate, 1950, 1952; Soons, 1971; Hessell, 1983) and, more recently, of 4-5 years (Fitzharris et al., 1992; Chinn, 1995).

Following the suggestion of Gellatly and Norton (1984), the debate on the link between climatic change and glacier behaviour has been widened from looking at either temperature or precipitation as the primary forcing mechanism to include a multivariate approach. Investigation of glacier mass balance (Woo and Fitzharris, 1992), snowline elevation changes (Chinn, 1995), modelling (Ruddell, 1995) and atmospheric circulation changes (Fitzharris et al., 1992; Hooker, 1995) have been undertaken. It is to the circulation changes that have taken place during the twentieth century that attention is now directed.

\section{PRESSURE ANOMALY FIELDS}

\section{New Zealand region}

Hessell (1983) used a north-south pressure index between Wellington and Christchurch to demonstrate that a significant relationship exists between the westerly geostrophic component of the wind and advances and retreats of the Franz Josef Glacier. Fitzharris and Hay (1989) and Fitzharris et al. (1992) reconstructed sea-level pressure patterns for the area $100^{\circ} \mathrm{E}$ to $140^{\circ} \mathrm{W}$ by $15^{\circ} \mathrm{S}$ to $60^{\circ} \mathrm{S}$ over the period 1911 to 1989 using the methods of Jones and Wigley (1988) and Jones (1991). In addition they determined zonal and meridional pressure gradients and geostrophic indices between Dunedin and Auckland, and Christchurch and Hobart respectively. Dividing the glacier's twentieth century history into a slow retreat period up to 1950, a more rapid retreat over the next three decades and a marked advance in the 1980s, they established that a significant relationship exists between glacier terminal positions and circulation changes in the westerlies and on the southern margin of the subtropical high to the north of New Zealand, particularly in summer. Examining these relationships, Hooker (1995) has determined mean sea-level pressure anomalies for the advance and retreat phases of the glacier during accumulation and ablation seasons (Figure 2).

Before proceeding to consider pressure anomaly fields, it is worth pointing out that it is a well established fact that if north-easterly airflow on to the South Island of New Zealand increases, then areas to the east of the Southern Alps experience more cloud, less sunshine and increased rainfall, while the west coast becomes clear, sunny and dry as a consequence of the foehn effect associated with offshore airflow (Sturman and Tapper, 1996; Kidson, 1997). With south-westerly airflow on to the west coast, the reverse pattern occurs on both sides of the mountains, with increasing cloud, diminishing sunshine and increasing precipitation to the west of the mountains. 

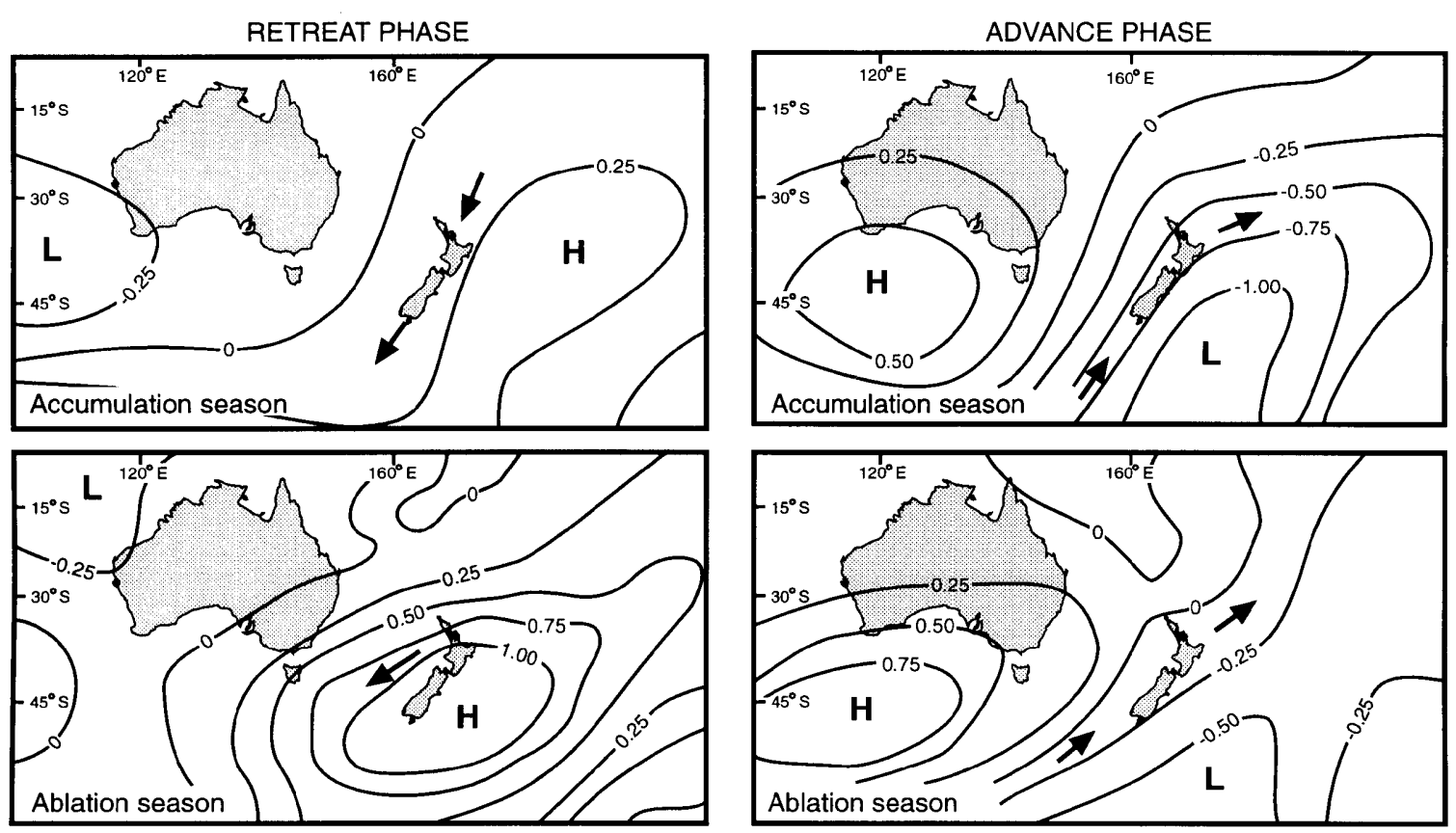

Figure 2. Mean sea-level pressure anomalies (hPa) for advance and recession phases of the Franz Josef Glacier during accumulation and ablation seasons based on 1911-1989 data (after Hooker, 1995)

These alternative situations are usually associated with changes in the Southern Oscillation Index (Gordon, 1985, 1986), but not exclusively so.

During the retreat phase of the Franz Josef Glacier, surface pressure fields in the New Zealand sector of the Southern Hemisphere show positive anomalies over the south-western Pacific Ocean to the east of New Zealand at about $45^{\circ} \mathrm{S}$ (Hooker, 1995) (Figure $2(\mathrm{left})$ ). These are stronger in the ablation season than in the accumulation season. Changes in precipitation, temperature and moisture transport are examined and associations with the Southern Oscillation Index are investigated. A weak low pressure anomaly is to be observed over the eastern Indian Ocean to the south-west of Australia. Under such conditions north-easterly wind anomalies prevail over the Southern Alps, a fact of importance because they reduce the amount of precipitation falling as snow during the accumulation season. At the same time, with this flow regime, cloud cover decreases over the west coast of the South Island, solar radiation is at a maximum and temperatures rise, resulting in increased ablation. Simultaneously, the total quantity of precipitation decreases as the westerlies weaken, especially in the ablation season, and as they retreat poleward. Concomitant southward movement of the subtropical anticyclone takes place during the ablation season (Hooker, 1995). The South Pacific Convergence Zone also moves southward in association with stronger trade winds and increased north-easterly flow over New Zealand (Kiladis and van Loon, 1988; Hay et al., 1993). Many of these features are associated with La Niña events and a positive pressure anomaly in the ablation season over New Zealand (Hooker, 1995).

In direct contrast, during the advance phase surface pressure anomaly fields reverse and a low develops to the east of New Zealand at about $50^{\circ} \mathrm{S}$. This is stronger in the accumulation season than in the ablation season (Figure 2 (right)). Positive pressure anomalies are generated south of Western Australia in both accumulation and ablation seasons. South-westerly wind anomalies affect the west coast of New Zealand and the glacier catchment as the westerlies expand equatorward and strengthen in the accumulation season. This results in increased cloud, reduced solar radiation receipt and a drop in temperature, particularly in the ablation season. Precipitation increases. In the ablation season, the flow patterns appear to be more westerly than south-westerly as the belt of persistent anticyclones south of Australia moves further north (Gordon, 1986; Fitzharris et al., 1992). Many of these features are associated with El Niño events and a negative pressure anomaly in the accumulation season over and to the east of New Zealand (Hooker, 1995). 


\section{The South African region}

Within the southern African sector of the Southern Hemisphere, distinctive circulation changes occur between the summer rainfall region extended wet and dry spells shown in Figure 1. The pressure anomaly fields at the surface and at $500 \mathrm{hPa}$ for the wet spell of 1972-1973 to 1978-1979 and the dry spell of 1963-1964 to 19701971 illustrate the point (Miron and Tyson, 1984). During wet years, positive pressure anomalies are to be observed to the south of South Africa (Figure 3). These are associated with easterly wind anomalies, i.e. a weakening of the circumpolar westerlies in the region of $40^{\circ} \mathrm{S}$. In direct contrast, during dry spells and periods of extended drought in southern Africa, negative pressure anomalies develop to the south of Africa, westerly anomalies are observed in the mid-latitude windfield and the westerlies strengthen.

The pressure changes are consistent with those occurring on the scale of days to weeks (Rubin, 1956; Triegaardt and Kits, 1963), months (Tyson, 1986; Taljaard, 1987) and seasons (Tyson, 1986; Taljaard and Steyn, 1991). Likewise, they are consistent with the notion that the Little Ice Age (Tyson, 1986; Tyson and Lindesay, 1992) and Last Glacial Maximum (Tyson, 1986; Cockcroft et al., 1987; Cohen and Tyson, 1995) in southern Africa were associated with invigorated westerly circulation in a poleward-expanded circumpolar vortex in the region. By the same token, it is thought that the wet hypsithermal period over southern Africa at around 6000 years BP was the result of invigorated tropical circulation in the region, associated with easterly wind anomalies and enhanced moisture advection polewards from the tropics (Tyson, 1986; Cohen and Tyson, 1995).
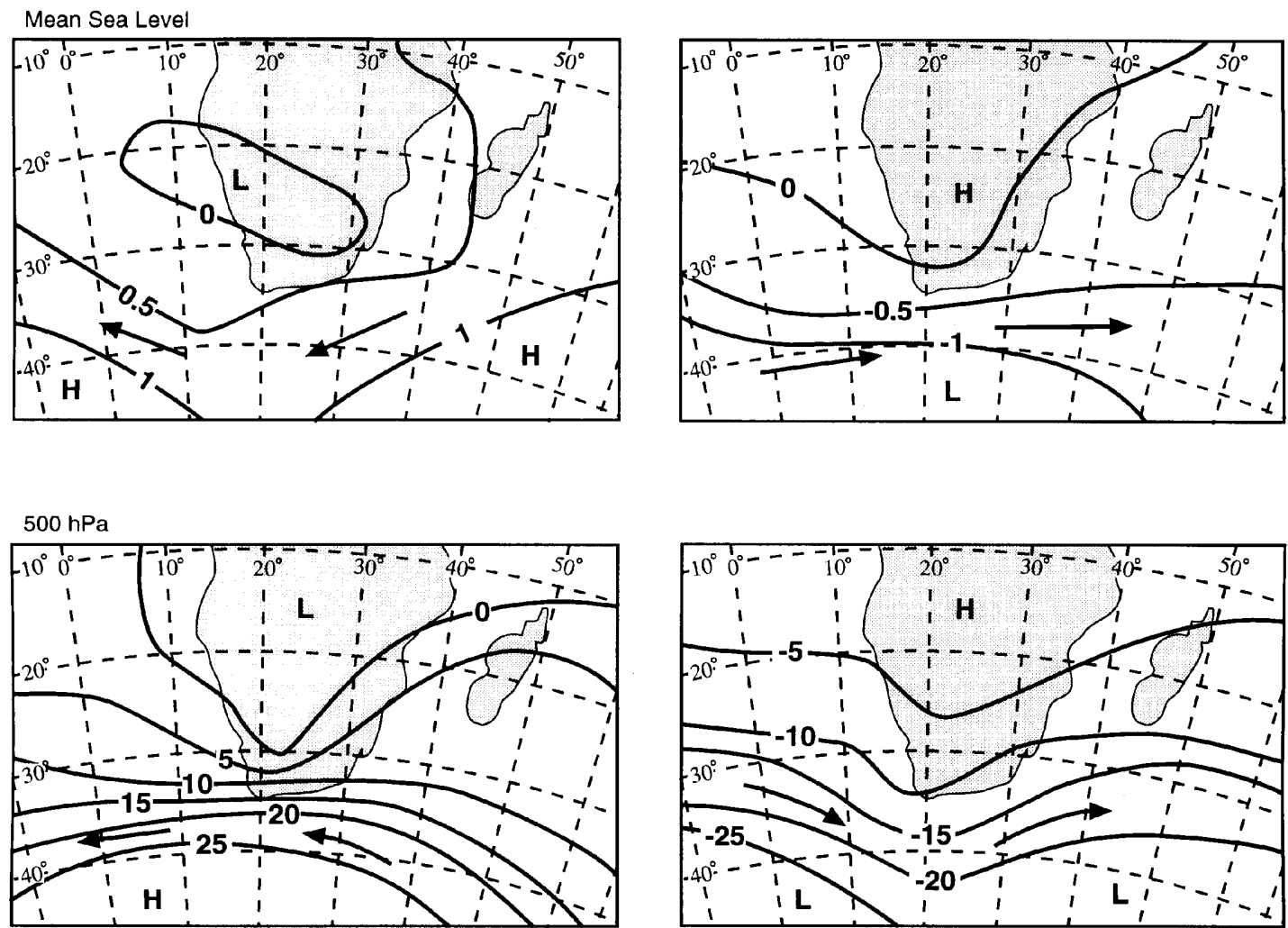

Figure 3. Mean sea-level (hPa) and $500 \mathrm{hPa}(\mathrm{gpm})$ pressure anomalies for the extended wet spell of 1972-1973 to 1978-1979 and the dry spell of 1963-1964 to 1970-1971 (after Miron and Tyson, 1984) 


\section{DISCUSSION}

In both the New Zealand and southern African sectors of the Southern Hemisphere, El Niño-Southern Oscillation (ENSO) events linked to changes in the Southern Oscillation Index and the Walker Circulation exert a discernible influence on climate in general and precipitation in particular. Gordon $(1985,1986)$ and Folland and Salinger (1995) have reviewed the effect of ENSO on New Zealand weather and climate. Annual temperature anomalies are positively correlated with the Southern Oscillation Index, particularly in the northern and eastern parts of North Island, where about 35 per cent of temperature variance is accounted for by variations in the index (Salinger et al., 1995). In general, El Niño and a negative Southern Oscillation Index produce an increase in the westerly component of wind, which in turn produces increased precipitation over the west coast of the South Island. La Niña and a positive index, in contrast, are associated with a greater incidence of north-easterly airflow and a diminution of west coast rainfall. The complexity of the linkage between ENSO and local patterns of rainfall and temperature over New Zealand has been explored by Mullan (1995), who shows that the simple relationship of below-average temperature with El Niño and the opposite with La Niña is incorrect for much of the South Island. It is now suggested that negative temperature anomalies occur during both ENSO extremes. The relationship is non-linear and probably related to the role of cloud development in north-easterly airstreams. El Niño produces a drop in maximum and minimum temperatures as the circulation adjusts to a greater frequency of south-westerly airflow, whereas La Niña results in a cloud-induced drop in the maximum temperature only (Mullan, 1995). Furthermore, the nature of the ENSO circulation relationship in the New Zealand sector appears to have varied during the twentieth century, with a mode change at around 1950. The interaction of global warming processes, ENSO and volcanic eruptions may be the cause of this complexity.

A link between ENSO events and the advance and recession of the Franz Josef Glacier has been argued. Thus the 1947-1951 and 1965-1967 advances were both preceded by periods with a high frequency of negative values of the Southern Oscillation Index (Brazier et al., 1992). Likewise, 1977-1978, 1982-1983, 1986-1988 and 19901995 have all been El Niño years, or years of strong negative index, and have been associated with the largest and longest sustained advance of the glacier this century (Brazier et al., 1992; Fitzharris et al., 1992; Hooker, 1995). Notwithstanding, recent work suggests that on the west coast the ENSO effect may not be as strong as hitherto has been supposed. Only about 10-15 per cent of the inter-annual temperature variance on the west coast may be ascribed to ENSO at statistically significant levels. Although the correlation between precipitation and the index is negative for the area, it accounts for less than 10 per cent of the variance and is not statistically significant (Salinger et al., 1995). Pressure anomaly fields for periods longer than El Niño events illustrate that more than just ENSO forcing is at work in producing the observed glacial fluctuations. The link to the circulation changes around southern Africa suggests the same.

El Niño events are associated with droughts over southern Africa. Of the total inter-annual variance in rainfall over South Africa, up to 25 per cent is accounted for by changes in Southern Oscillation Index and the Walker Circulation (Lindesay, 1988). If the data are stratified according to the sign of the stratospheric Quasi-biennial Oscillation, the maximum explained variance rises to over 36 per cent when the Oscillation is westerly. With the easterly phase of the Quasi-biennial Oscillation, the variance accounted drops to about 16 per cent (Mason and Lindesay, 1993). In the southern African region, changing sea-surface temperature exerts a major effect on the changing interannual distribution of rainfall on the subcontinental scale (Walker, 1990; Jury and Pathack, 1991; Mason, 1995). The influence of sea-surface temperature is greatest during the austral summer months (Mason, 1995; Jury, 1996). The association between rainfall and sea-surface temperature is strongest in the case of the equatorial Indian Ocean, but the significance of ocean areas further south and in the Atlantic Ocean should not be discounted (Walker and Lindesay, 1989; Walker, 1990; Mason, 1995; Mason and Jury, 1997). In part, the influence of sea-surface temperatures in the equatorial Indian Ocean is a reflection of an increase (decrease) in temperatures in the region that typically occurs during El Niño (La Niña) events (Cadet, 1985; Suppiah, 1988; Meehl, 1993; Jury et al., 1994; Mason, 1995). However, Indian Ocean warm events do occur independently of ENSO forcing (Cadet, 1988) and not all sea surface temperature-rainfall links can be traced to ENSO (Mason and Tyson, 1992; Tyson, 1993; Mason, 1995). Inter-annual variability of southern African rainfall is the consequence of multiple forcing.

The inter-annual interactions between tropical and temperate circulation systems over southern Africa are important in determining the overall conditions favouring the occurrence of a run of either wet or dry years. This 
is particularly so in respect to the changing regions of preferred formation of tropical-temperate troughs, standing wave structure, diabatic heat and momentum transports (Harangozo and Harrison 1983; Barclay et al., 1993), changing seasonal and annual pressure anomaly fields (Miron and Tyson, 1984; Taljaard and Steyn, 1991), mean divergence anomaly fields (Tyson, 1986) and moisture advection (D'Abreton and Lindesay, 1993; D'Abreton and Tyson, 1994, 1996). The circulation components responsible for wet and dry spells over southern Africa are illustrated schematically in Figure 4. The interaction produces a tendency for runs of wet and dry years to produce an oscillation in the rainfall of the summer rainfall region with a period of around 18 years (Tyson, 1971, 1986; Tyson et al., 1975). In addition to the major peak at about this period, others in the range 3-4 years (ENSO) and at 2.3 years (Quasi-biennial Oscillation) are to be observed. The quasi-18-year peak occurs in tree-ring series and has been traced back to the early seventeenth century (Visagie, 1985). The oscillation has also been observed in ocean temperatures around South Africa (Mason, 1990; Mason and Jury, 1997) and appears to be similar to that reported at about 21 years in Southern Hemisphere sea-surface temperatures (Folland et al., 1984). In the eastern equatorial Pacific Ocean, inter-decadal variability in sea-surface temperatures (Hurrell and van Loon, 1984) shows an out-of-phase association with the 18-year rainfall oscillation over southern Africa (Mason and Jury, 1997), although there is no evidence of similar low frequency variability in the Southern Oscillation Index (Allan et al., 1996). In summary, although the ENSO phenomenon is important in affecting climate variability over both New Zealand and South Africa, it does not appear to provide an adequate mechanism for explaining the teleconnection observable at inter-decadal scales. It is therefore necessary to examine the features of the atmospheric circulation responsible for advances and retreats of the Franz Josef Glacier and for prolonged wet and dry years over South Africa in more detail.

In the New Zealand sector, the full range of circulation variations influencing advance and retreat of the westcoast glaciers is summarized in Figure 5. Earlier arguments that advance and recession were the product of either temperature or precipitation changes alone (Hessell, 1983; Salinger et al., 1983; Gellatly and Norton, 1984) have evolved into an understanding of a more complicated and subtle process. Ablation in summer is favoured by higher frequencies of lighter north-easterly winds of tropical origin, warmer, drier conditions and increased sunshine. Accumulation in winter is enhanced by an increased frequency of stronger south-westerly winds, precipitation, lower temperatures and less sunshine (Fitzharris et al., 1992; Woo and Fitzharris, 1992; Hooker, 1995). Simple modelling supports the notion that it is the interplay of precipitation and temperature effects that control New Zealand glacier changes (Ruddell, 1995). More importantly, it is atmospheric circulation changes that modulate changes of precipitation and temperature.

Despite the fact that the New Zealand region is subject to strong westerly airflow, it may also experience markedly contrasting air masses, owing to relatively strong meridional components of circulation in this sector of the Southern Hemisphere (Basher and Thompson, 1996). The consequence is the significant rises (falls) in temperature that result from northerly (southerly) wind anomalies. The meridional circulation is enhanced by frequent anticyclonic blocking to the south-east of New Zealand. A good example of such a situation is the cold winter of 1992, when anomalous southerly flow was caused by the persistent location of low pressure systems to the south-east of the country owing to downstream anticyclonic blocking over the central South Pacific. This situation resulted in both cooler air and lower sea-surface temperatures throughout the region (Basher and Thompson, 1996).

As the atmospheric circulation responds to hemispheric-scale forcings, so the New Zealand region experiences periods dominated by either zonal or meridional flow. The circulations most conducive to glacier retreat on the west coast are those that favour enhanced north-easterly airflow. Typically this occurs when blocking anticyclones develop to the south-east of the South Island. Blocking tends to develop preferentially in the winter (accumulation) season in association with a breakdown of the westerlies (Sinclair, 1996). At such times advection of warm, moist air over the country increases rainfall to the north-east, but diminishes precipitation to the southwest. In contrast, a strong zonal westerly regime produces the opposite (Kidson, 1994). Blocking situations are also associated with stronger trade winds, a poleward displacement of the westerlies and the disturbances therein (Fitzharris et al., 1992). Contemporaneously, meridional flow increases, an upper wave develops with a trough over Tasmania (Sinclair, 1995) and the subtropical jet splits, with the southward displacement of the polar jet branch (Kidson and Sinclair, 1995; Sinclair, 1996). 


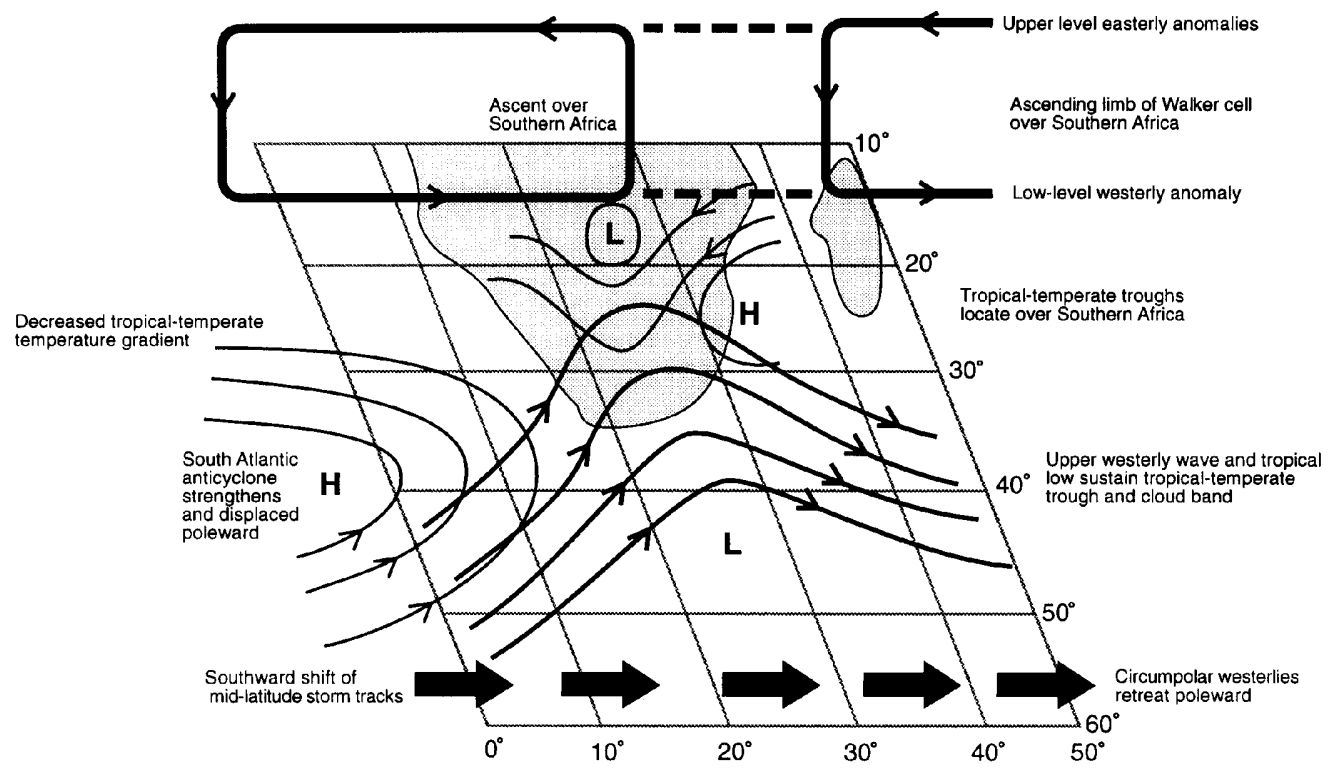

DRY SPELLS

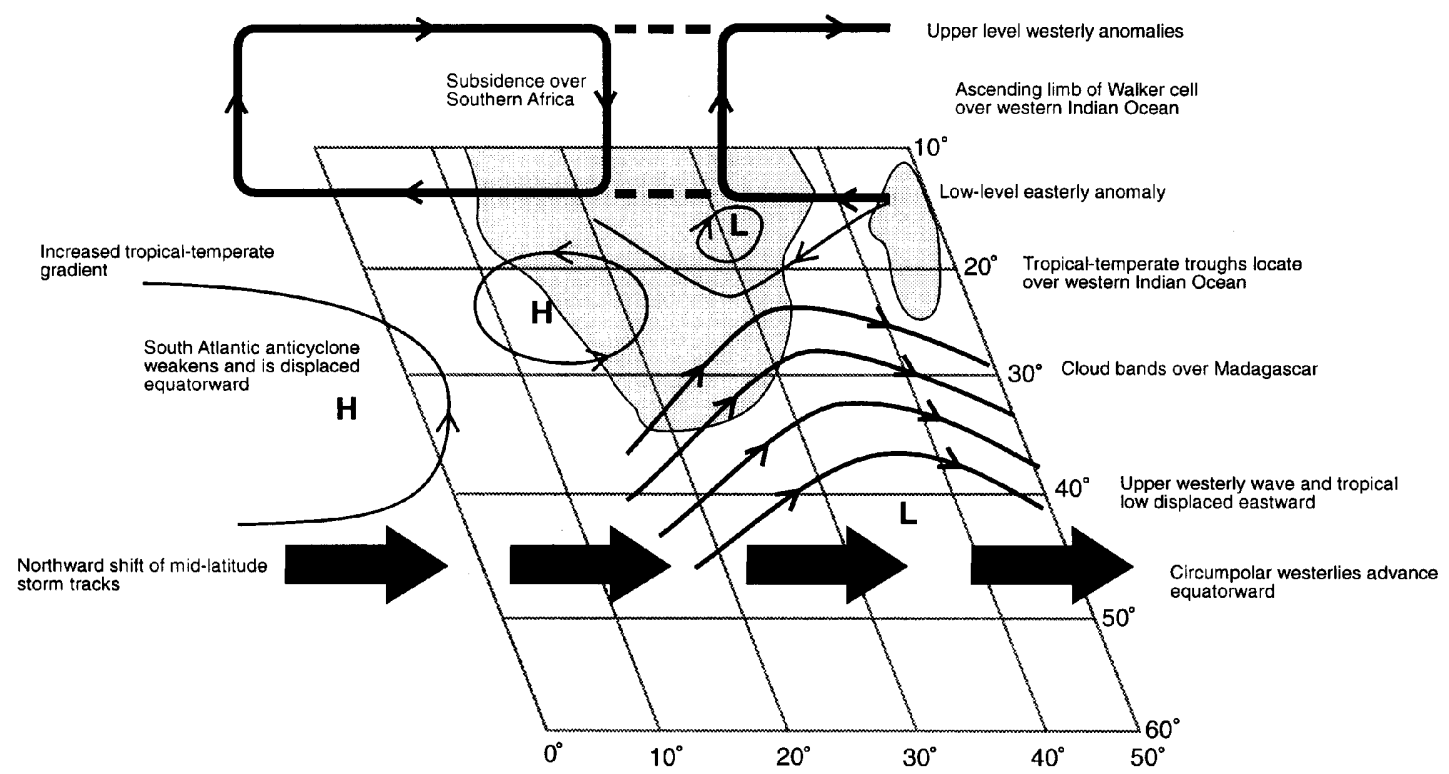

Figure 4. Schematic representation of circulation changes taking place between extended wet and dry spells in South Africa 


\section{RETREAT PHASE}

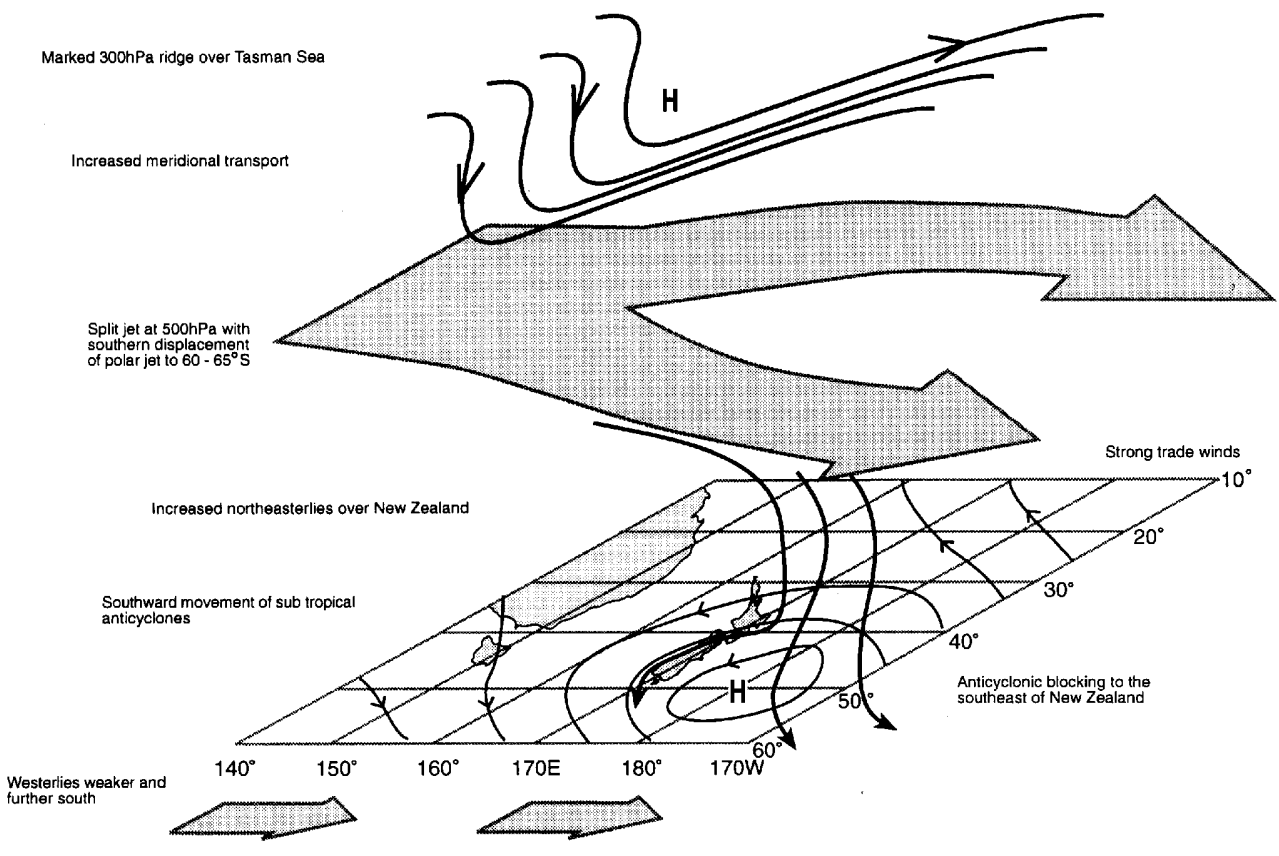

ADVANCE PHASE

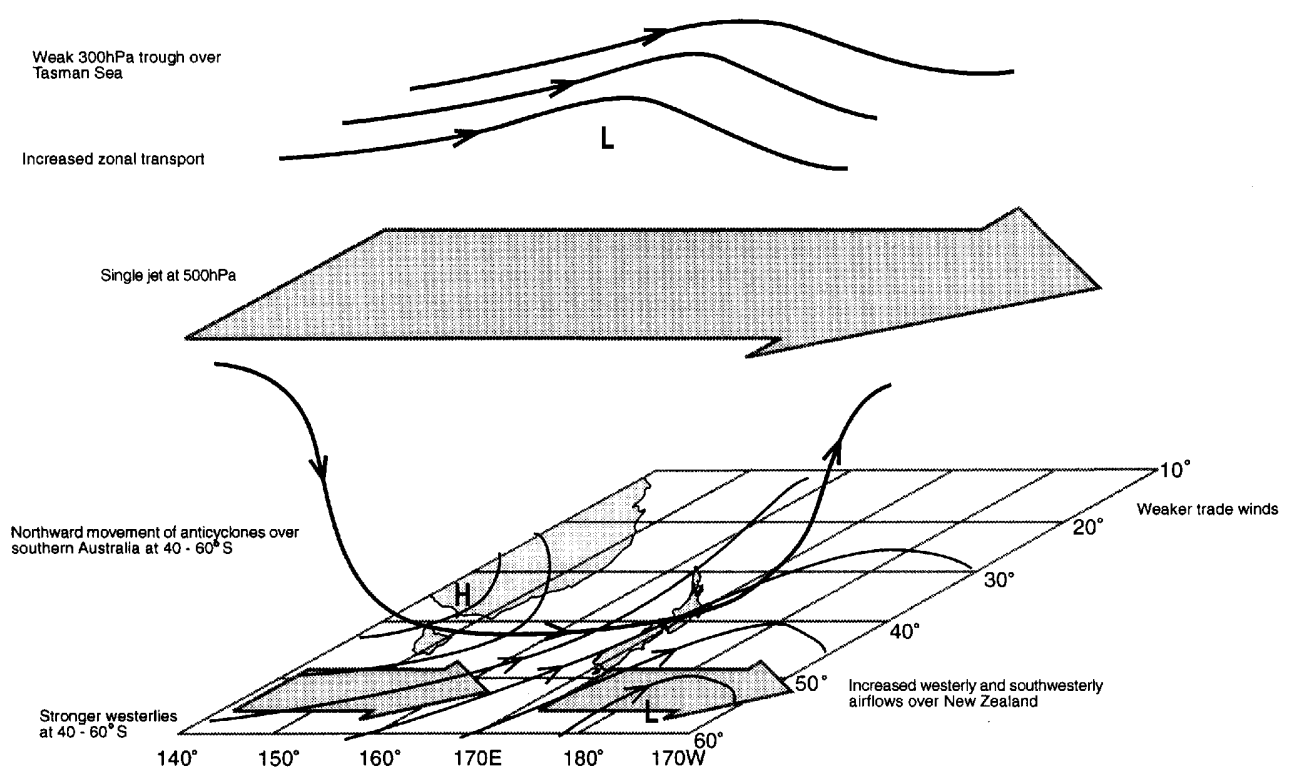

Figure 5. Schematic representation of circulation changes taking place between periods of advance and recession of the Franz Josef Glacier in New Zealand 
Situations most conducive to glacier advance on the west coast are those favouring an enhancement of zonal flow, weaker trade winds, equatorward movement of the westerlies and the subtropical anticyclone (Fitzharris et al., 1992), a single jet and weaker upper westerly waves (Sinclair, 1995). These features of the general circulation are summarized schematically in Figure 5 and are part of broad perturbations in the hemispheric circulation having a near-decadal oscillation, on which higher-frequency fluctuations, such as ENSO and the Quasi-biennial Oscillation, and aperiodic events, such as volcanic eruptions like that of Pinatubo, are superimposed.

Major regional changes in atmospheric circulation must logically be associated with local processes which control ablation and accumulation of the alpine glaciers (Hay and Fitzharris, 1988). Field research has shown net radiation and convective heat and moisture fluxes are important factors affecting both the névé and terminus regions of the glaciers (Hay and Fitzharris, 1988; Ishikawa et al., 1992). Convective fluxes play the greater role at lower elevations by influencing the melt processes, which are broadly controlled by such air mass characteristics as cloud and temperature. Snow accumulation in the Franz Josef area is determined largely by the strength and frequency of the westerly flow, which controls the amount of orographic precipitation received. The proportion of precipitation falling as snow is a crucial factor in determining the growth or decay of the glacier and this is determined by the nature and origin of the airmass involved. The more south-westerly the trajectory of the air mass, the greater the probability of solid precipitation.

The advances of the Franz Josef Glacier during the twentieth century have occurred with an oscillation of about 20 years that is antiphase to the quasi-18-year South African rainfall oscillation. Some evidence exists to suggest a weak fluctuation of about the same period in the precipitation of the south-western parts of the South Island that is the inverse of the rainfall changes to the east of the continental divide (Salinger et al., 1995). Earlier work also reports some evidence of a quasi-20-year fluctuation in New Zealand rainfall (Vines, 1980, 1982). The mean regional New Zealand annual temperature series for the period 1871-1993 indicates the presence of interdecadal variability and an observed warming of $0.7^{\circ} \mathrm{C}$ (Folland and Salinger, 1995). Minima in the temperature series are consistent with times of Franz Josef Glacier advance. Spectral analysis of the linearly-detrended series reveals a peak somewhat above 16 years (Folland and Salinger, 1995), close, but not identical, to the 21-year oscillation in Southern Hemisphere sea-surface temperatures (Folland et al., 1984). The spectral peak is absent in tropical western Pacific sea-surface temperatures (Folland and Salinger, 1995), but is evident in the eastern equatorial Pacific (Hurrell and van Loon, 1994) with a period of about 18 years (Mason, 1997). Dendrochronological studies of Northofagus species at subalpine sites west of the main divide show variance spectra of growth season (December-March) temperature for the period 1853-1978 with peaks at around 20 years and another at about 3 years (Norton et al., 1989; Norton and Palmer, 1992). Rainfall oscillations with periods around 20 years have been reported for Victoria, Australia and for parts of southern South America (Vines, 1980, 1982). Whether further oscillations on decadal scales will be found in Southern Hemisphere geophysical data remains to be seen. Such variability should be sought and the relationship between the various oscillations must be examined. The relationships between New Zealand glacial advance and South African drought suggest that additional teleconnections may be identified that would shed further light on the mechanisms of important hemispheric-scale modes of low-frequency variability.

Given the absence of ENSO forcing at periods around two decades and the correspondence between oscillations of this period in New Zealand and South Africa and the cohesive links that have been demonstrated between the circulation anomalies during South African droughts and Franz Josef Glacier advances, it would appear that ENSO forcing as a primary driving mechanism for west coast glacial advances has been overemphasized. Important though the regional effect of ENSO is in New Zealand, the teleconnections between the advances of the Franz Josef Glacier and South African droughts, and the circulation adjustments that accompany each, suggest that mechanisms other than ENSO play a dominant role in determining inter-annual variability in the Southern Hemisphere. Changes in the strength and location of the westerlies in the New Zealand and South African sectors of the hemisphere appear to play a crucial role.

Strengthened westerlies in an equatorward expansion of the circumpolar vortex have been held to account for the Last Glacial Maximum in a colder New Zealand experiencing higher precipitation in the west of the South Island and drier conditions in the north and east of North Island (Harrison et al., 1984; Salinger, 1984). Similarly, it has been posited that the same circulation changes would have brought about a contemporaneous cool, dry period in southern Africa (Tyson, 1986; Cockcroft et al., 1987; Cohen and Tyson, 1995). Both notions gain 
credence from the circulation changes that explain the teleconnections between South African rainfall fluctuations and the advances of the Franz Josef Glacier.

The teleconnection between New Zealand and South Africa may be linked to changes in standing wave 3 of the Southern Hemisphere general circulation, and is a reflection of either a change in the amplitude or a shift in the preferred location of the ridges and troughs of the wave, or both (Mason, 1997). Ridges are typically located at about $40^{\circ} \mathrm{E}$, just to the east of South Africa, and at about $165^{\circ} \mathrm{E}$, just to the west of New Zealand (van Loon and Jenne, 1972). During the retreat phase of the New Zealand west coast glaciers, a strengthening of an upper-level ridge over the country (Figure 5) implies a strengthening and eastward shift of the wave-3 ridge in the region. An eastward shift of the wave in the southern African sector, away from the east coast of South Africa, permits the development of a westerly trough over the subcontinent and an enhancement of wet-period poleward transport of heat, moisture and momentum over the east coast (Figure 4). Conversely, during the advance stages of the glaciers, wave 3 weakens in amplitude and shifts to the west (Figure 5) allowing a trough to develop over New Zealand. Contemporaneously, the ridge of wave 3 shifts westward over South Africa (Figure 4). A decrease in the amplitude of the wave results in the weakened poleward transport of heat, moisture and momentum that is characteristic of dry-spell conditions. Further work is needed to establish the reasons for these shifts in wave patterns and possible links with sea-surface temperature increases in the eastern Pacific Ocean.

\section{CONCLUSIONS}

In the New Zealand sector of the southern hemisphere, the advance (retreat) phase of the Franz Josef Glacier is associated with negative (positive) pressure anomalies to the south-east of the country and stronger (weaker) westerlies in the accumulation season. Contemporaneously, equatorward (poleward) displacement of the westerlies occurs, accompanied by equatorward (poleward) displacement of the subtropical high in the ablation season, anomalous tropical westerly component (easterly component) flow in the accumulation season, a negative (positive) Southern Oscillation Index, wetter (drier) conditions and cooler (warmer) weather in the ablation season.

In the South African sector, systematic changes are also observed. Extended dry spells (wet spells) are associated with the development of deep negative (positive) pressure anomaly fields to the south of the country, increased (decreased) pressures over the continent, equatorward (poleward) extension of the westerlies and weakening (strengthening) of tropical easterly airflow and moisture advection. At the same time, eastward (westward) displacement of the region for the preferred development of tropical-temperate troughs over the Indian Ocean (continent) occurs, accompanied by a negative (positive) Southern Oscillation Index, and warmer (cooler) conditions.

The twentieth century advances of the Franz Josef Glacier have all followed 4-5 years after changes in atmospheric circulation patterns in the New Zealand region that favour a greater frequency of occurrence of south-westerly winds. The advances also occur within 4 years of the development of a run of predominantly dry years in South Africa, where the circulation likewise has changed to favour increased airflow in the circumpolar westerlies. The tropical easterly component winds that promote recession of the Franz Josef Glacier, correspond to tropically induced wind anomalies of the same direction that favour the occurrence of runs of wet years in South Africa. The oscillations in South African rainfall and the Franz Josef glacial advances are out of phase. Both have periods around 20 years, both may be linked to similar oscillations in other geophysical series and both correspond to oscillations with similar periods in regional sea-surface temperatures in the surrounding oceans.

Provided twentieth century inter-decadal variability patterns that have been observed in New Zealand and South Africa do not change, it is likely that after several years of stagnation or recession the Franz Josef Glacier will again advance at some time during the first decade of the twenty-first century. At the same time, South Africa is likely to be experiencing yet another of its extended spells of predominantly dry years. Such speculations need to be placed on a firmer footing. Further work needs to be done on southern hemisphere inter-annual climatic variability on decadal scales. The inter-decadal teleconnections between the droughts of South Africa and the advances of the Franz Josef Glacier are linked to such large-scale circulation changes that responses in other data series elsewhere in the hemisphere must exist and need to be sought. 


\section{ACKNOWLEDGEMENTS}

This work was completed while the first author was an Erskine Visiting Fellow at the University of Canterbury. Figures were prepared by Bill Mooney, Michelle Rogan and Philip Stickler. The anomaly maps in Figure 2 were kindly supplied by Bronwen Hooker and her work is acknowledged with appreciation. Originally it was thought that the second glacial advance considered in this paper prevailed from 1921 to 1934 . The South African rainfall data suggested this might be in error. Dr Trevor Chinn of the Institute of Geological and Nuclear Sciences, Dunedin kindly investigated the original claims for the advance, found an error and was able to give correct dates for the advance as 1925-1934. Rainfall changes in South Africa did indeed enable an error in the New Zealand glacier data to be detected! Dr Chinn's help is much appreciated. The travel associated with this research was funded by the Universities of Canterbury and the Witwatersrand.

\section{REFERENCES}

Allan, R. J., Lindesay, J. A. and Parker, D. E. 1996. El Niño Southern Oscillation and Climate Variability, CSIRO, Collingwood, Australia, $405 \mathrm{pp}$.

Barclay, J. J., Jury, M. R. and Landman, W. 1993. 'Climatological and structural differences between wet and dry troughs over southern Africa in the early summer', Meteorol. Atmos. Phys., 51, 41-54.

Basher, R. E. and Thomspon, C. S. 1996. 'Relationship of air temperatures in New Zealand to regional anomalies in sea-surface temperture and atmospheric circulation', Int. J. Climatol., 16, 405-425.

Brazier, V., Owens, I. F., Soons, J. M. and Sturman, A. P. 1992. 'Report on the Franz Josef Glacier', Z. Geomorphol., 86, 35-49.

Cadet, D. L. 1985. 'The Southern Oscillation over the Indian Ocean', J. Climate, 5, 189-212.

Chinn, T. J. 1989. 'Glaciers of New Zealand', U.S. Geol. Surv. Pap., 1386-H-2, H22-H48.

Chinn, T. J. H. 1995. 'Glacier fluctuations in the Southern Alps of New Zealand determined from snowline elevations', Arct. Alp. Res., 27, 187-197.

Chinn, T. J. H. 1996. 'New Zealand glacier responses to climate change of the past century', N.Z. J. Geol. Geophys., 39, 415-428.

Cockcroft, M. J., Wilkinson, M. J. and Tyson, P. D. 1987. 'The application of a present-day climatic model to the late Quaternary in southern Africa', Climatic Change, 10, 161-181.

Cohen, A. and Tyson, P. D. 1995. 'Sea surface temperatures during the Holocene on the south coast of Africa: implications for terrestrial climate and rainfall', Holocene, 5, 304-312.

D'Abreton, P. C. and Lindesay, J. A. 1993. 'Water vapour transport over southern Africa during wet and dry late summer months', Int. J. Climatol., 13, 151-170.

D'Abreton, P. C. and Tyson, P. D. 1994. 'Divergent and non-divergent water vapour transport over southern Africa during wet and dry conditions', Meteorol. Atmos. Phys., 136, 1-13.

D'Abreton, P. C. and Tyson, P. D. 1996. 'Three-dimensional kinematic modelling of water vapour transport over southern Africa', Water SA., 22, 297-306.

Fitzharis, B. B. and Hay, J. E. 1989. 'Glaciers - can they weather the storm of climatic change?' Proceedings of the New Zealand Geography Conference, Dunedin, New Zealand Geography Society, pp. 284-291.

Fitzharris, B. B., Hay, J. E. and Jones, P. D. 1992. 'Behaviour of New Zealand glaciers and atmospheric circulation changes over the past 130 years', Holocene, 2, 97-106.

Folland, C. K. and Salinger, M. J. 1995. 'Surface temperature trends and variations in New Zealand and the surrounding ocean, 1871-1993', Int. J. Climatol., 15, 1195-1218.

Folland, C. K., Parker, D. E. and Kates, F. 1984. 'Worldwide marine temperature fluctuations 1856-1981', Nature, 310, $670-673$.

Gordon, N. D. 1985. 'The Southern Oscillation: a New Zealand perspective', J. R. Soc. N. Z., 15, 137-155.

Gordon, N. D. 1986. 'The Southern Oscillation and New Zealand weather', Mon. Wea. Rev., 114, 371-387.

Gellatly, A. F. and Norton, D. A. 1984. 'Possible warming and glacier recession in the South Island, New Zealand', N.Z. J. Sci., 27, 381-388.

Haeberli, W. 1995. 'Glacier fluctuations and climate change detection-operational elements of a world wide monitoring strategy', World Meteorol. Organ. Bull. 44, 23-31.

Harangozo, S. H. and Harrison, M. S. J. 1983. 'On the use of synoptic data in indicating the presence of cloud bands over southern Africa', $S$. Afr. J. Sci., 79, 413-414.

Harrison, S. P., Metcalfe, S. E., Pittock, A. B., Salinger, M. J. and Street-Perrott, F. A. 1984. 'A climate model of the last glacial/interglacial transition based on palaeotemperature and palaeohydrological evidence', in Vogel, J. C. (ed.), Late Cainozoic Palaeoclimates of the Southern Hemisphere, A.A. Balkema, Rotterdam, pp. 21-34.

Hay, J. E. and Fitzharris, B. B. 1988. 'The synoptic climatology of ablation on a New Zealand glacier', J. Climatol., 8, $201-215$.

Hay, J., Salinger, J., Fitzharris, B. B. and Basher, R. 1993. 'Climatological seesaws in the southwest Pacific', Wea. Climate, 13, 9-21.

Hessell, J. W. D. 1983. 'Climatic effects on the recession of the Franz Josef Glacier', N.Z. J. Sci., 26, 315-320.

Hooker, B. L. 1995. Advance and retreat of the Franz Josef Glacier in relation to climate. Unpublished dissertation, Department of Geography, University of Otago, Dunedin, $62 \mathrm{pp}$.

Hurrell, J. W. and van Loon, H. 1994. 'A modulation of the atmospheric annual cycle in the Southern Hemisphere', Tellus, 46A, 325-338.

Ishikawa, N., Owens, I. F. and Sturman, A. P. 1992. 'Heat balance characteristics during fine periods on the lower parts of the Franz Josef Glacier, South Westland, New Zealand', Int. J. Climatol., 12, 397-410.

Johannesson, T., Raymond, C. and Waddington, E. 1989. 'Time scale for adjustment of glaciers to changes in mass balance', J. Glaciol., 35, 355-369. 
Jones, P. D. 1991. 'Southern hemisphere sea level pressure data: an analysis and reconstructions back to 1951 and 1911', Int. J. Climatol., 11, 585-607.

Jones, P. D. and Wigley, T. M. L. 1988. 'Antarctic gridded sea level pressure data: an analysis and reconstruction back to 1957', J. Climate, 1, $1199-1220$.

Jury, M. R. 1996. 'Regional teleconnection patterns associated with summer rainfall over South Africa, Namibia and Zimbabwe', Int. J. Climatol., 16, 135-153.

Jury, M. R. and Pathack, B. M. R. 1991. 'A study of climate and weather variability over the tropical southwest Indian Ocean', Meteorol. Atmos. Phys., 47, 37-48.

Jury, M. R., McQueen, C. A. and Levey, K. M. 1994. 'SOI and QBO signals in the African region', Theor. Appl. Climatol., 50, $103-115$.

Keen, C. S. 1971. Rainfall spectra and the delimitation of rainfall regimes in South Africa. Unpublished MSc dissertation, University of the Witwatersrand, Johannesburg, $138 \mathrm{pp}$.

Kidson, J. W. 1994. 'Relationship of New Zealand daily and monthly weather patterns to synoptic weather types', Int. J. Climatol., 14, 723737.

Kidson, J. W. 1997. 'The utility of surface and upper air data in synoptic climatological specification of surface climatic variables', Int. J. Climatol., 17, 399-413.

Kidson, J. W. and Sinclair, M. R. 1995. 'The influence of persistent anomalies on Southern Hemisphere storm tracks', J. Climate, 8, 19381950.

Kiladis, G. and van Loon, H. 1988. 'The Southern Oscillation. Part VII: meteorological anomalies over the Indian and Pacific sectors associated with the extremes of the oscillation', Mon. Wea. Rev., 116, 120-136.

Lindesay, J. A. 1988a. 'Southern African Rainfall, the Southern Oscillation and a Southern Hemisphere semi-annual cycle', J. Climatol., 8, $17-30$.

Lindesay, J. A. 1988b. The Southern Oscillation and atmospheric circulation changes over southern Africa. Unpublished PhD thesis, University of the Witwatersrand, Johannesburg, $284 \mathrm{pp}$.

Lawrence, D. B. and Lawrence, E. G. 1965. 'Glacier studies in New Zealand', Mazama, 47(13), 17-27.

Mason, S. J. 1992. Sea surface temperatures and South African rainfall variability. Unpublished PhD thesis, University of the Witwatersrand, Johannesburg, $235 \mathrm{pp}$.

Mason, S. J. 1995. 'Sea-surface temperature-South African rainfall associations, 1910-1989', Int. J. Climatol., 15, $119-135$.

Mason, S. J. 1996. 'Rainfall trends over the Lowveld of South Africa', Clim. Change, 32, 35-54.

Mason, S. J. 1997. 'South Africa's 18-year rainfall cycle: a link with sea surface temperatures in the equatorial Pacific?', S. Afri. J. Sci., submitted.

Mason, S. J. and Jury, M. R. 1997. 'Climatic variability and change over southern Africa: a reflection on underlying processes', Prog. Phys. Geogr., 21, 23-50.

Mason, S. J. and Lindesay, J. A. 1993. 'A note on the modulation of Southern Oscillation-southern African rainfall associations with the Quasi-biennial Oscillation', J. Geophys. Res., 98, 8847-8850.

Mason, S. J. and Tyson, P. D. 1992. 'The modulation of sea surface temperature and rainfall associations over southern Africa by solar activity and the Quasi-Biennial Oscillation', J. Geophys. Res., 97, 5847-5856.

Meehl, G. A. 1993. 'A coupled air-sea biennial mechanism in the tropical Indian and Pacific regions: role of the oceans', J. Climate, 6, 31-41.

Miron, O. and Tyson, P. D. 1984. 'Wet and dry conditions and pressure anomaly fields over South Africa and the adjacent oceans, 19631979’, Mon. Wea. Rev., 112, 2127-2132.

Mullan, A. B. 1995. 'On the linearity and stability of Southern Oscillation-climate relationships for New Zealand', Int. J. Climatol., 15, 13651386.

Ngara, T., McNaughton, D. L. and Lineham, S. 1983. 'Seasonal rainfall fluctuations in Zimbabwe', Zim. Agric. J., 80, $149-150$.

Norton, D. A. Briffa, K. R. and Salinger, M. J. 1989. 'Reconstruction of New Zealand summer temperature to 1730 AD using dendroclimatic techniques', Int. J. Climatol., 9, 633-644.

Norton, D. A. and Palmer, J. G. 1992. 'Dendroclimatic evidence from Australasia', in Bradley, R. S. and Jones, P. D. (eds), Climate Since AD 1500, Routledge, London, pp. 463-482.

Oerlemans, J. 1994. 'Quantifying global warming from the retreat of glaciers', Science, 26, 243-245.

Raper, S. C. B., Briffa, K. R. and Wigley, T. M. L. 1996. 'Glacier changes in northern Sweden from AD 500: a simple geometric model of Storglaciaren', J. Glaciol., 42, 341-351.

Rubin, M. J. 1956. 'The associated precipitation and circulation patterns over southern Africa', Notos, 5, 53-59.

Ruddell, A. R. 1995. Recent glacier and climate change in the New Zealand Alps. Unpublished PhD thesis, School of Earth Sciences, University of Melbourne, $252 \mathrm{pp}$.

Salinger, M. J. 1984. 'New Zealand climate: the last 5 million years', in Vogel, J. C. (ed.), Late Cainozoic Palaeoclimates of the Southern Hemisphere, A. A. Balkema, Rotterdam, pp. 21-34.

Salinger, M. J., Heine, M. J. and Burrows, C. J. 1983. 'Variation of the Stocking (Te Wae Wae) Glacier, Mount Cook, and climatic relationships', N.Z. J. Sci., 26, 321-338.

Salinger, M. J., Fitzharris, B. B., Hay, J. E., Jones, P. D., Macveigh, J. P. and Schmidley-Lrleu, I. 1995. 'Climate trends in the south-west Pacific', Int. J. Climatol., 15, 285-302.

Sinclair, M. R. 1995. 'A climatology of cyclogenesis for the Southern Hemisphere', Mon. Wea. Rev., 123, 1601-1619.

Sinclair, M. R. 1996. 'A climatology of anticyclones and blocking for the Southern Hemisphere', Mon. Wea. Rev., 24, 245-263.

Soons, J. M. 1971. 'Recent changes in the Franz Josef Glacier', Proceedings of the Sixth New Zealand Geography Conference, Christchurch, August 1970, N.Z. Geogr. Soc. Conf. Ser. 6(1), 195-200.

Sturman, A. P. and Tapper, N. J. 1996. The Weather and Climate of Australia and New Zealand, Oxford University Press, Melbourne, 476 pp. Suggate, R. P. 1950. 'Franz Josef and other glaciers of the Southern Alps, New Zealand', J. Glaciol., 1, 422-429.

Suggate, R. P. 1952. 'Franz Josef Glacier, March 1951', N.Z. J. Sci. Technol., 33, 299-304.

Suppiah, R. 1988. 'Relationships between Indian Ocean sea surface temperature and rainfall of Sri Lanka', J. Meteorol. Soc. Jpn, 66, $103-111$.

Taljaard, J. J. 1987. The Anomalous Weather and Climate Systems over South Africa during Summer 1975-1976, South Africa Weather Bureau Technical Paper, No. 16, Pretoria, 80 pp. 
Taljaard, J. J. and Steyn, P. C. L. 1991. Relationships between Atmospheric Circulation and Rainfall in the South African Region, South Africa Weather Bureau Technical Paper, No. 24, Pretoria, 62 pp.

Triegaardt, D. O. and Kits, A. 1963. 'Die drukveld by verskillende vlakke oor suidelike Afrika en aangrensende oseane tydens vyfdaagse reen-en droe periodes in suid Transvaal en noord-Vrystaat gedurende die 1960-1961 somer', S. A. Wea. Bur. Newsl., 186, $37-43$.

Tyson, P. D. 1971. 'Spatial variation of rainfall spectra in South Africa', Ann. Assoc. Am. Geogr., 61, 711-720.

Tyson, P. D. 1986. Climatic Change and Variability in Southern Africa, Oxford University Press, Cape Town, 220 pp.

Tyson, P. D. 1993. 'Recent developments in modelling climate change in southern Africa', S. Afri. J. Sci., 89, 494-505.

Tyson, P. D., Dyer, T. G. J. and Mametse, M. N. 1975. 'Secular changes in South African rainfall: 1880 to 1972', Q. J. R. Meteorol. Soc., 101, 817-833.

Tyson, P. D. and Lindesay, J. A. 1992. 'The climate of the last 200 years in southern Africa', Holocene, 2, 271-278.

Van Heerden, J., Terblanche, D. E. and Schulze, G. C. 1988. 'The Southern Oscillation and South African summer rainfall', J. Climatol., 8, 577-597.

Van Loon, H. and Jenne, R. L. 1972. 'The zonal harmonic standing waves in the Southern Hemisphere', J. Geophys. Res., 77, $992-1003$.

Vines, R. G. 1980. 'Analyses of South African rainfall', S. Afri. J. Sci., 76, 404409.

Vines, R. G. 1982. 'Rainfall patterns in southern South America and possible relationships with similar patterns in South Africa', S. Afri. J. Sci., 78, 457-459.

Visagie, P. J. 1985. An Investigation into Wet and Dry Cycles of Rainfall in South Africa, Report to Hydrology Engineering Division, Electricity Supply Commission, Sandton, 39 pp.

Walker, N. D. 1990. 'Links between South African summer rainfall and temperature variability of the Agulhas and Benguela Current Systems', J. Geophys. Res., 95, 3297-3319.

Walker, N. D. and Lindesay, J. A. 1989. 'Preliminary observations of oceanic influences on the February-March 1988 floods in central South Africa', S. Afr. J. Sci., 85, 164-169.

Woo, M. and Fitzharris, B. B. 1992. 'Reconstruction of mass balance variations for Franz Josef Glacier, New Zealand, 1913 to 1989 ', Arct. Alp. Res., 24, 281-290.

Wratt, D. S., Ridley, R. N., Sinclair, M. R. Larsen, H. Thompson, S. M. Henderson, R., Austin, G. L., Bradley, S. G., Auer, A., Sturman, A. P., Owens, I., Fitzharris, B. B., Ryan, B. F. and Gayet, J. F. 1996. 'The New Zealand Southern Alps Experiment', Bull. Am. Meteorol. Soc., 77, 683-692. 